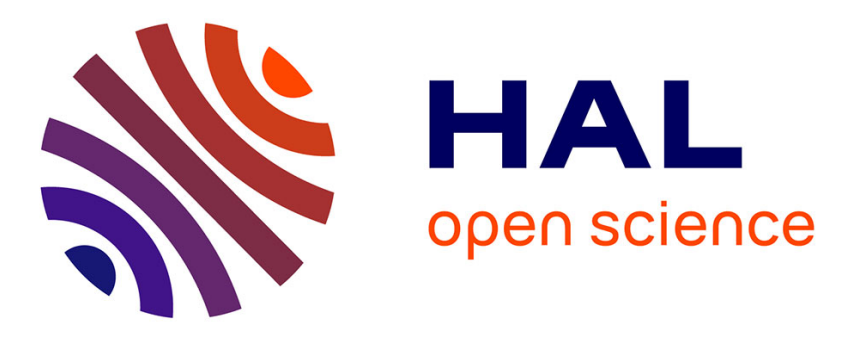

\title{
FTIR characterisation of the chemical composition of Silurian miospores (cryptospores and trilete spores) from Gotland, Sweden
}

Philippe Steemans, K. Lepot, C.P. Marshall, Alain Le Hérissé, Emmanuelle J. Javaux

\section{To cite this version:}

Philippe Steemans, K. Lepot, C.P. Marshall, Alain Le Hérissé, Emmanuelle J. Javaux. FTIR characterisation of the chemical composition of Silurian miospores (cryptospores and trilete spores) from Gotland, Sweden. Review of Palaeobotany and Palynology, 2010, 162 (4), pp.577-590. 10.1016/j.revpalbo.2010.07.006 . insu-00558990

\section{HAL Id: insu-00558990 \\ https://hal-insu.archives-ouvertes.fr/insu-00558990}

Submitted on 15 Feb 2011

HAL is a multi-disciplinary open access archive for the deposit and dissemination of scientific research documents, whether they are published or not. The documents may come from teaching and research institutions in France or abroad, or from public or private research centers.
L'archive ouverte pluridisciplinaire HAL, est destinée au dépôt et à la diffusion de documents scientifiques de niveau recherche, publiés ou non, émanant des établissements d'enseignement et de recherche français ou étrangers, des laboratoires publics ou privés. 


\title{
FTIR characterisation of the chemical composition of Silurian cryptospores from Gotland, Sweden.
}

Philippe Steemans ${ }^{a,}{ }^{,}$, Kevin Lepot ${ }^{a}$, Craig P. Marshall ${ }^{b}$, Alain Le Hérissé ${ }^{c}$, Emmanuelle J. Javaux $^{\text {a }}$

${ }^{a}$ Paléobotanique, Paléopalynologie, Micropaléontologie (PPM), University of Liège, Bâtiment B-18, allée du 6-Août, 4000 Liège-1, Belgium.

${ }^{\mathrm{b}}$ Department of Geology, The University of Kansas, Lawrence, Kansas 66045-7613 USA.

'. Université de Brest, CNRS UMR6538, Domaines Océaniques, Institut Universitaire Européen de la Mer, Batiment G, 6 Avenue Le Gorgeu 29238 Brest cedex 3, France

* Corresponding author. Tel: 0032436653 33; fax: 003243665338.

E-mail address: P.Steemans@ulg.ac.be (Philippe Steemans)

\begin{abstract}
To better understand the biological affinities of cryptospores, micro-FTIR (Fourier transform infrared) spectroscopy analysis has been carried out on isolated specimens from the Late Silurian of Gotland. The geobiochemical results have been compared to spectra of trilete spores, chitinozoans and leiospheres from the same sample. The palynomorphs are all very well preserved as attested by their pale yellow to orange colour indicative of a low thermal maturity. Micro-FTIR spectroscopy indicates that cryptospores display very similar spectra to those of the trilete spores, which are composed of sporopollenin characterised by absorption bands from aliphatic $\mathrm{C}$-H in methylene $\left(\mathrm{CH}_{2}\right)$ and methyl $\left(\mathrm{CH}_{3}\right)$ groups, aromatic $(\mathrm{C}=\mathrm{C}$ and $\mathrm{C}-\mathrm{H})$ groups and $\mathrm{C}=\mathrm{O}$ groups of carboxylic acids. The sporopollenin composition of the cryptospore wall observed here is additional evidence demonstrating the embryophytic affinity of the cryptospores. In addition, several variations in other bands in the spectra of the different miospore morphospecies are evidenced and may be linked to their biological affinity or palaeoecological history.
\end{abstract}

Keywords: Fourier transform infrared spectroscopy, cryptospore, trilete spore, sporopollenin, Silurian, Gotland

\section{Introduction}

The earliest evidence for land plants are propagules termed cryptospores because of their primitive aspect, the lack of a trilete mark, and because their parent plants were originally unknown (Richardson et al., 1984; Steemans, 2000). They are observed since the Darriwilian (Llanvirn) from Saudi Arabia (Strother et al., 1996) and from the Czech Republic (Vavrdová, 1990a,b) up to at least the Middle Devonian (Breuer et al., 2007). They show unusual configurations in comparison with the younger spores of tracheophytes (Richardson, 1996a,b; Steemans and Wellman, 2004; Steemans et al., in-press). Cryptospores are preserved either as monads or as obligate dyads or as tetrads that remain permanently fused. At the border of their contact area, each spore of dyads or tetrads shows an annular thickening. Cryptospores are either naked or enclosed within a thin envelope. The envelope and/or the wall of the cryptospores may be ornamented by various elements. The ornamentation is usually inconspicuous in the oldest species, but Late Silurian and Early Devonian specimens become more similar to trilete spores. During the last ten years, evidence for an embryophytic affinity has increased, particularly due to the discovery of in situ cryptospores (in situ meaning in plant sporangia) and subsequent observations of their ultrastructure (e.g. Wellman et al., 
1998b; Taylor, 2003; Gensel, 2008; and references therein), embryophytes being land plants living in terrestrial habitats, in contrast with the related green algae that are aquatic. The most common Ordovician and Silurian cryptospores are Tetrahedraletes medinensis Strother and Traverse emend. Wellman and Richardson 1993 (tetrad), Dyadospora murusdensamurusattenuata morphon Steemans et al. 1995 (dyad) and Gneudnaspora (Laevolancis) divellomedia Balme, 1988 var. divellomedia Breuer et al. 2007 (monad). These three taxa have also been found in situ, in sporangia of rhyniophytoid plants (e.g. Wellman et al., 1998a,b; Edwards et al., 1999). They range from the Ordovician to the Lower/Middle Devonian. They have a pandemic repartition.

Trilete spores are mainly produced by tracheophytes. The oldest specimens are Ordovician in age (Steemans et al., 2009b) from a Saudi Arabian locality, where they are extremely rare. They become more abundant in the early Silurian and very abundant from the late Silurian up to extant time. Their wall is composed of sporopollenin (Traverse, 2007). Recent papers have characterised, using FTIR spectroscopy, the composition of a range of fossilised spores and artificially matured trilete spores, showing that these spores consist of sporopollenin (Yule et al., 2000; Dutta, 2006; Dutta et al., 2007). Sporopollenin is an organic polymer of extremely high stability originating from the multilayered outer wall (exine) of miospores (miospore is a general term including spore plants, pollens, cryptospores etc., see Steemans, 2000). The ultrastructure of the exine varies according to the taxa. Sporopollenin is an extremely resistant macromolecule that may be fossilised and preserved over several hundred millions of years and may resist high pressure metamorphism (Bernard al., 2007). The chemical structure of this non-hydrolysable polymer is still a matter of debate, although unbranched alkyl chains and phenyl propanoid units would be expected to be the main building blocks of sporopollenin (Vandenbroucke \& Largeau, 2007) and references therein). This biomolecule is thus composed of oxygenated aliphatic and aromatic units, together with alkyl, carbonyl, carboxylic and ester groups, as well as lesser amounts of phenolic units (Cody et al., 1996; Vandenbroucke \& Largeau, 2007). The most important diagenetic effect during fossilization is the thermal maturation causing the colour change of the miospores (from pale yellow to black) with increasing depth of burial Here we show for the first time the chemical composition of cryptospores, in order to decipher their biological affinity. Micro-FTIR spectroscopy has already demonstrated its efficiency in the analysis of fossilised palynomorphs such as acritarchs (e.g. Marshall et al., 2005; Javaux and Marshall, 2006), chitinozoans (e.g. Jacob et al., 2007) and trilete spores (e.g. Yule et al., 2000). We have applied the same method to analyze the composition of cryptospores, trilete spores, as well as chitinozoans and leiospheres from the same Late Silurian sample from Gotland. Despite their small sizes (usually ca. 30-60 $\mu \mathrm{m}$ in diameter), the very good preservation of these palynomorphs and the abundance of cryptospores and trilete spores together in the same samples allow direct comparison of the different types of fossils that have undergone the same diagenetic conditions.

\section{Material and methods}

Sample 580 was collected by A. Le Hérissé from the Kättelviken outcrop at the southwestern tips of the Gotland Island (Fig. 1). It consists of a thin micaceous grey siltstone layer of the Burgsvik Formation. The Burgsvik Formation (Fig. 2) is characterised by coarser sediments than in the underlined Eke Formation. Sedimentary structures such as lamination, hummocky cross stratification, load structures, and cross bedding occur in the sandstone (Hagström, 1997). The succession of sandstones and oolithes displays a transition from a supratidal to intertidal environment in the Burgsvik Formation. The overlying Hamra and Sundre 
formations are composed of limestones. The Burgsvik Formation has been dated as Ludlow in age by way of acritarchs (Le Hérissé, 1989) and spores (Hagström, 1997). It is the richest formation in continental palynomorphs of the Silurian from Gotland. However, among the continental palynomorphs, rare chitinozoans and acritarchs are present.

The palynomorphs were extracted from siltstone using a gentle laboratory treatment that is less damaging to the palynomorphs than the standard technique using centrifugation and heavy liquids (Grey, 1999). The samples were gently teased (not crushed) into small fragments. They were then immersed in $40 \% \mathrm{HF}$ for 9 days. The residue was sieved in distilled water after one week to neutralize the acid. No oxidative agent was used at any stage of the protocol in order to prevent modification of the composition of the palynomorphs. Single palynomorphs in distilled water were handpicked from the kerogen macerates under a dissecting microscope using a micropipette.

The palynomorphs are very well preserved, as shown by their pale yellow to orange colour which is indicative of a low thermal alteration (Batten, 1996). The colour of chitinozoans indicates a maximum diagenetic temperature of $100^{\circ} \mathrm{C}$ (Laufeld, 1974). Five specimens of each cryptospore morphospecies have been extracted: T. medinensis (P1. 1, Figs. 1-3), D. murusdensa-murusattenuata (P1. 1, Figs. 6-8) and G. divellomedia (Pl. 1, Figs. 9-10). In addition, as the ornamented tetrad Pachytetras rugosa Hagström 1997 (P1. 1, Figs. 4-5) is particularly abundant in the sample, 5 of them were isolated for comparison with $T$. medinensis. Moreover, to compare the cryptospores with trilete spores, 5 specimens of simple laevigate trilete spores of Ambitisporites/Retusotriletes type (Pl. 1, Figs. 11-12) were also selected. Those specimens were chosen as they are morphologically close to the selected cryptospores (except $P$. rugosa, which is ornamented). It is important to remember that the term of species is improperly used in palaeopalynology, as the parent plants that produced the large majority of those miospores are unknown. In the following sections, we use the term morphospecies, bearing in mind that one morphospecies may contain several true biological species, or that one parent plant may produce several morphospecies.

Recently, micro-FTIR data have been obtained on chitinozoans (Dutta et al., 2007; Jacob et al., 2007) and acritarchs (Marshall et al., 2005; Javaux and Marshall, 2006), so we will compare three specimens of each of those marine palynomorphs isolated from the Gotland material to evaluate with the previous published results.

Micro-FTIR spectra were recorded on individual specimens in the $4000-600 \mathrm{~cm}^{-1}$ range with the co-addition of 128 - 512 scans at a spectral resolution of $4 \mathrm{~cm}^{-1}$ using a Bruker Tensor 27. The spectrometer was coupled to a Bruker Hyperion II microscope equipped with a $15 \mathrm{x}$ objective. Specimens were placed onto a $\mathrm{ZnSe}$ matrix in ambient air (resulting in weak $\mathrm{CO}_{2}$ absorbance bands at $2400 \mathrm{~cm}^{-1}$ ). For each specimen the largest possible area was used for analysis. All transmitted spectra were obtained after subtraction of the background spectrum from the sample spectrum. Spectra were manipulated within Opus $6.5^{\mathrm{TM}}$ software. Spectra were recorded on 3 to 5 specimens of each morphospecies, according to their abundance in the samples. In some cases several measurements have been done on single specimen, but as spectra were exactly similar a single spectrum was retained per specimen. Because three is the minimum of recorded spectra for every morphotype, only three spectra are shown in the figures. In table 1, absorption bands ratios are medium values measured on the sum spectrum of all spectra acquired on a given morphotype.

To compare spectra and to analyse the relative absorption values, a baseline correction was applied to the spectra using the concave rubberband correction method of the software. 
Spectral bands were assigned with reference to the literature (e.g. Arouri et al., 1999, 2000; Coates, 2000; Yule et al., 2000; Marshall et al., 2005; Javaux and Marshall, 2006; Marshall et al., 2006a). Second derivatives were applied to the spectra to highlight bands where the spectra showed weak resolution.

\section{Results}

\subsection{FTIR analysis of chitinozoan and leiosphere}

\subsubsection{Undetermined chitinozoan}

The micro-FTIR spectrum of the chitinozoan (Figs. 3, 4.5, 4.6 and Tbl. 1) is very similar to those published by Jacob et al. (2007) and Dutta et al. (2007) on a palynological material of similar coalification grade. Both aliphatic (between $2800-3000 \mathrm{~cm}^{-1}$ and at 1375 and $1455 \mathrm{~cm}^{-}$ $\left.{ }^{1}\right)$ and aromatic $\left(1617 \mathrm{~cm}^{-1}\right.$ and $\left.700-900 \mathrm{~cm}^{-1}\right)$ absorption bands are present. The spectrum shows a high aromatic content and a relatively low aliphatic content as reported by Jacob et al. (2007) (Tbl. 1, ratio $3925 \mathrm{~cm}^{-1} / 1604 \mathrm{~cm}^{-1}=0.43$ ). The aromatic ether group absorptions at ca. $1260 \mathrm{~cm}^{-1}$ is stronger than reported in the literature.

\subsubsection{Leiosphere}

The micro-FTIR spectrum of the leiosphere (Figs. 3, 4.7, 4.8 and Tbl. 1) is characterized by a very strong absorption from aliphatic and carbonyl groups. The aliphatic carbon absorption $\left(2925 \mathrm{~cm}^{-1}\right)$ is very high relative to the other bands in the spectrum, indicating the high aliphatic content of this palynomorph. A strong band is centred at $1627 \mathrm{~cm}^{-1}$, which is beyond the frequency range of simple aromatic ring stretch vibrations (ca. $1580-1615 \mathrm{~cm}^{-1}$ ). It either indicates the presence of alkenes, ketones (Coates, 2000), or polyaromatic structures (Hudgins and Sandford, 1998a, b). The latter assignment is preferred, as the characteristic absorption from vinyl C-H of alkenes (out of plane bend) between $700-1000 \mathrm{~cm}^{-1}$ is absent and the position of the carbonyl band $\left(1707 \mathrm{~cm}^{-1}\right)$ is more consistent with carboxylic acids than with ketones.

The spectrum shows several similarities to that of a Leiosphaeridia spp. published by Marshall et al. (2005). Their Neoproterozoic specimens display a moderate absorption from carboxyl groups and a moderate absorption from aliphatic groups. In addition, their specimens show a relatively stronger absorption from aromatic groups, the latter being centred at 1600 $\mathrm{cm}^{-1}$ instead of $1627 \mathrm{~cm}^{-1}$ for the leiosphere studied here. This difference could be due to different degrees of maturation of the organic matter. The leiospheres from Gotland are indeed less mature (pale yellow to pale orange) than the Neoproterozoic and Mesoproterozoic leiospheres (yellow-light brown) studied by Marshall et al. (2005). The Mesoproterozoic leiospheres have a higher degree of thermal alteration as expressed by their darker colour and accordingly have a greater aromatic content and lower aliphatic and carbonyl content with respect to the Neoproterozoic and the leiospheres in this study.

On the other hand, the aliphatic content of the leiosphere relative to aromatic carbon (Tbl. 1, ratio $\left.2925 \mathrm{~cm}^{-1} / 1604 \mathrm{~cm}^{-1}=1.78\right)$ is very high compared to that of the chitinozoan $(0.43)$. Since both fossils have undergone similar maturation conditions, this suggests that the difference in aliphatic content is inherited from distinct compositions of the parent organisms. 
The leiosphere spectrum here shows some similarities to that of Vanguestainidium cucurbitulum Steemans et al. 2009a, an enigmatic giant Givetian acritarch from Libya (Steemans et al., 2009a). They are very well preserved and yellow in colour. The similarities include very intense absorption of aliphatic (between $2800-3000 \mathrm{~cm}^{-1}$ and at 1375 and 1455 $\left.\mathrm{cm}^{-1}\right)$ and carboxyl $\left(1705 \mathrm{~cm}^{-1}\right)$ groups. However, the aromatic absorption is relatively very weak for $V$. cucurbitulum. The spectroscopic study of $V$. cucurbitulum is in accord with previous studies of the aliphatic- and carboxyl-rich resistant biopolymer "algaenan" isolated from extant Botryococcus braunii Kützing 1849 (Largeau et al., 1986; Marshall et al., 2006) and of the Neoproterozoic acanthomorph acritarch Tanarium conoideum (Marshall et al, 2005). The leiosphere studied here is composed of an aliphatic-rich biopolymer which can also be assigned to an algaenan biopolymer, therefore suggesting a green algae affinity. Recent studies suggest the possibility of aliphatic molecules forming as a result of diagenetic processes (e.g. Versteegh et al., 2004; Kodner et al., 2009; but see e.g. Gupta, et al., 2007, for a different view and response by de Leeuw, 2007 and response by Gupta et al. 2007). De Leeuw et al. (2006) suggested two separate and parallel pathways to explain the presence of aliphatic polymers in sediments: (i) selective preservation of non-hydrolysable aliphatic biomacromolecules such as cutan and algaenan and their possible further transformation by additional cross-linking and (ii) oxidative polymerization of low molecular weight functionalized lipids, a process similar to the drying of oil paint made from linseed oil. The diagenetic process called "oxidative polymerisation" has been demonstrated in the preservation of Eocene dinoflagellates (Versteegh et al., 2004), where the original organic wall had not been fossilized, but the dinoflagellate cells were replaced by an organic mould called "dinocasts". These "dinocasts" have been formed post-mortem by oxidative polymerization of the dinoflagellate internal lipids and possibly lipids from external sources. However these casts, showing some traces of para-tabulation, are not hollow but represent a spongy infilling of the dinoflagellates. They resist acid-maceration but are easily destroyed by shaking, so cannot be confused with microfossil walls.

Kodner et al. (2009) investigated the occurrence of algaenan in extant algae, and noted its limitation to a few freshwater taxa. The author concluded that the abundance of aliphatic kerogens in marine sediments must be of diagenetic origin. Although this is certainly a possibility, as suggested by the studies mentioned above, in the present study (and a previous study by Marshall et al, 2005), specimens of one morphospecies from the same sample with the same diagenetic history show a composition similar to algaenan and co-occur with species that do not have this composition. Therefore we think that the original biological signal of algaenan is preserved in these specific cases, even though it is possible that all the biopolymers preserved in the walls of the various palynomorphs may have been "aliphaticized". It is also possible that the degree of diagenetic aliphatisation of biopolymers depends on their original composition, and not only on the diagenetic conditions.

Our microchemical approach suffers from the scarce current knowledge of the ultrastructure and chemical composition of resistant cell walls produced by extant microorganisms (Javaux and Marshall, 2006). Therefore, at this point, the presence of an algaenan-like biopolymer cannot be considered as conclusive evidence for algal affinity. Considerable (ongoing) work needs to be done to understand the taxonomic and phylogenetic significance of various biopolymers and their transformation by diagenesis and metamorphism in the rock record.

\subsubsection{Conclusions for marine palynomorphs}

Despite the fact that the organic matter analysed in various studies (e.g. Yule et al., 2000; Marshall et al., 2005, 2006; Dutta, 2006; Dutta et al., 2007; Jacob et al., 2007) and the present 
study originate from different regions (and therefore has been affected by different geological histories), it is possible to differentiate the micro-FTIR spectrum acquired from the chitinozoan with respect to the spectrum acquired from the leiosphere. Variation in spectra acquired from palynomorphs from the same single sample shows that the inferred differences in biopolymer composition are mainly controlled by the biological source rather than thermal maturity or other geological processes up to the exposure of the geological sedimentary layers in outcrops.

\subsection{FTIR analysis of trilete spores and cryptospores}

A common feature to all the miospores below is the absorption from aromatic carbon centred at $1606 \mathrm{~cm}^{-1}$, whereas it is centred at higher and lower wavenumbers for the leiosphere $(1627$ $\left.\mathrm{cm}^{-1}\right)$ and the chitinozoan $\left(1613 \mathrm{~cm}^{-1}\right)$ respectively. Thus, the miospores here show consistently distinct aromatic carbon structures.

\subsubsection{Retusotriletes sp. / Ambitisporites sp. (trilete spores; Plate 1, Figs. 11-12)}

The micro-FTIR spectrum obtained from trilete spores (Fig. 3, 4.1-4.4 and Tbl. 1) shows medium aliphatic $\mathrm{CH}_{\mathrm{x}}$ bands in the region $2930-2850 \mathrm{~cm}^{-1}$. The ratio $2925 \mathrm{~cm}^{-1} / 1604 \mathrm{~cm}^{-1}$ equals 0.99 (Tbl. 1). The second derivative in the $1800-1200 \mathrm{~cm}^{-1}$ region demonstrates the presence of 5 bands: $1704,1610,1500,1455$ and $1376 \mathrm{~cm}^{-1}$. A shoulder assigned to carbonyl groups is present at about $1704 \mathrm{~cm}^{-1}$. The $1605 \mathrm{~cm}^{-1}$ band, corresponding to aromatic $\mathrm{C}=\mathrm{C}$ ring stretching, shows a strong absorbance. The shoulder at $1500 \mathrm{~cm}^{-1}$ reflects single aromatic $\mathrm{C}=\mathrm{C}$ rings as found in sporopollenin according to Rouxhet et al. (1980) and Yule et al. (2000). The band at $1455 \mathrm{~cm}^{-1}$ is assigned to $\mathrm{CH}_{2}$ and anti-symmetric $\mathrm{CH}_{3}$ deformation modes, and the band at $1376 \mathrm{~cm}^{-1}$ to symmetric $\mathrm{CH}_{3}$ deformation modes. The bands of variable width centred at about $1250-1270 \mathrm{~cm}^{-1}$ reveal aromatic ether functionalities. The band from phenol groups (ca. $1210 \mathrm{~cm}^{-1}$ ) is either present as a shoulder of similar height than that at $1265 \mathrm{~cm}^{-1}$, or forms an unresolved doublet with the latter. The main difference between the three spectra in Fig. 4 is in the variation in ether/alcohol group absorption between 1000$1270 \mathrm{~cm}^{-1}$, including the well defined bands at $1270,1210 \mathrm{~cm}^{-1}$ and $1023 \mathrm{~cm}^{-1}$ that show coincident variation. This variation is likely responsible for the variable pattern observed below about $1000 \mathrm{~cm}^{-1}$ : the spectrum in Fig. 4.4 shows a well-defined band from aromatic groups, whereas this region forms a plateau in the spectrum in Fig. 4.3 and flanks a rising baseline in the spectrum in Fig. 4.2. The aromatic absorption bands below $1000 \mathrm{~cm}^{-1}$ progressively turn into shoulders flanking the bands of increased absorption in the ether/alcohol wavenumber range.

The spectra of the trilete spores are very similar in their pattern and the position of the absorption bands to the sporopollenin analyzed in other fossil spores (e.g. Yule et al., 2000; Dutta, 2006;).

\subsubsection{Cryptospores}

3.2.2.1 Gneudnaspora divellomedia (monad; Plate 1, Figs. 9-10)

G. divellomedia is morphologically very similar to the trilete spores

Retusotriletes/Ambitisporites specimens analysed above. The difference between both is the 
absence of a trilete mark on the proximal face of the cryptospores. Chemically, these specimens are similar as shown by the FTIR spectra (Figs. 3, 5.1-5.4 and Tbl. 1). The same bands are present with more or less the same intensity. The main differences from the spectra acquired from the trilete spore are stronger aliphatic $\mathrm{C}_{\mathrm{H}} \mathrm{H}_{\mathrm{x}}$ bands between $2930-2860 \mathrm{~cm}^{-1}$ (Tbl. 1; ratio $2925 \mathrm{~cm}^{-1} / 1604 \mathrm{~cm}^{-1}, 1.34$ ). The ether/alcohol $v(\mathrm{C}-\mathrm{O})$ stretch absorption range $\left(1000-1270 \mathrm{~cm}^{-1}\right)$ shows variation similar to that observed in the spectra acquired from the trilete spores, albeit overall higher intensity.

\subsubsection{Dyadospora murusdensa-murusattenuata (dyad; Plate 1, Figs. 6-8)}

G. divellomedia is supposed to result from the separation of the two spores of Dyadospora into two monads. Therefore, morphologically both are very similar.

The FTIR spectra of the dyads are very similar to the monad spectra. The aliphatic content is also similar (Tbl. 1; ratio $2925 \mathrm{~cm}^{-1} / 1604 \mathrm{~cm}^{-1}, 1.43$ ).

\subsubsection{Tetrahedraletes medinensis (tetrad; Plate 1, Figs. 1-3)}

Morphologically, a tetrad is the result of the tetrahedral assembling of four monads.

The spectra (Figs. 3, 6.1-6.5 and Tbl. 1) present some differences with those of the previous miospore spectra, including: (i) the presence of a well defined and relatively intense aromatic $\mathrm{C}=\mathrm{C}$ band instead of a shoulder at $1500 \mathrm{~cm}^{-1}$ (indicative of a lower degree of condensation/substitution of aromatic units) together with a prominent band at ca. $820 \mathrm{~cm}^{-1}$ ( $p$-disubstituted aromatic rings); (ii) a well defined phenol band at $1210 \mathrm{~cm}^{-1}$ as well as a higher O-H absorption at $3422 \mathrm{~cm}^{-1}$; (iii) a lower aliphatic content (Tbl. 1; ratio $2925 \mathrm{~cm}^{-}$ $\left.1 / 1604 \mathrm{~cm}^{-1}, 0.85\right)$ that is closer to that of the trilete spores $(0.99)$. The coupled features ( $\left.\mathrm{i}+\mathrm{ii}\right)$ indicate an important content of $p$-alkyl substituted phenols (Iglesias et al., 2002).

An additional $T$. medinensis specimen characterised by a much thinner exine (Fig. 6.1) displays a spectrum different from the thicker specimen analysed above. It shares the following features with trilete spores and monad/dyad cryptospores: (i) strong $1500 \mathrm{~cm}^{-1}$ band present only as a shoulder; (ii) aromatic CH band in $900-600 \mathrm{~cm}^{-1}$ region is not clearly resolved as in the other spectra acquired from $T$. medinensis. In addition, the relatively lower aliphatic content (vs. compared to monad/dyad cryptospores) as well as the intermediate $\mathrm{O}-\mathrm{H}$ $\left(3410 \mathrm{~cm}^{-1}\right)$ absorption is similar to those of the trilete spores (Tbl. 1).

\subsubsection{Pachytetras rugosa (ornamented tetrad; Plate 1, Figs. 4-5)}

This tetrad is similar to T. medinensis but is ornamented by convolute muri on the distal exine surface.

The $\mathrm{C}=\mathrm{O}$ shoulder at $1704 \mathrm{~cm}^{-1}$ is slightly more pronounced than in the T. medinensis spectra (Figs. 3, 6.6-6.8 and Tbl. 1). The aromatic $\mathrm{C}=\mathrm{C}$ band at $1500 \mathrm{~cm}^{-1}$ is also present, as in $T$. medinensis. The most conspicuous difference from T. medinensis is the much stronger phenol absorbance $\left(1210 \mathrm{~cm}^{-1}\right)$.

\section{Interpretation of results}

\subsection{General chemical composition of miospore wall.}

All spectra collected from the miospores are very similar in their general line shape and position of the absorption bands with respect to the spectrum of the sporopollenin biopolymer 
in fossilised and modern trilete spores (e.g. Yule et al., 2000; Dutta, 2006). "Sporopollenin is characterised by aliphatic bands $\mathrm{CH}_{\mathrm{x}}\left(3000-2800\right.$ and $\left.1460-1450 \mathrm{~cm}^{-1}\right)$ and $\mathrm{CH} 3\left(1375 \mathrm{~cm}^{-1}\right)$ absorptions, aromatic $\mathrm{C}=\mathrm{C}$ group absorptions $1740-1700 \mathrm{~cm}^{-1}$ " (Dutta, 2006). Those results have been confirmed by Watson et al., 2007). In addition, the aromatic band $\left(1510 \mathrm{~cm}^{-1}\right)$ seems to reflect single aromatic rings, a characteristic feature of sporopollenin, peat and lignite (Watson et al., 2007). Therefore, we can demonstrate that the wall composition of the cryptospores analysed here is similar to the exine of the fossilised trilete spores. This is one more argument in favour of the hypothesis that they are produced by embryophytes.

All the miospore morphospecies, with the exception of $P$. rugosa, show intraspecific variations in their spectra line shapes. These differences concern mainly the ether and alcohol bands, and possibly the aromatic $\mathrm{C}-\mathrm{H}$ bands (below $1000 \mathrm{~cm}^{-1}$ ), although variation in the latter are difficult to estimate because of the baseline fluctuation caused by the very variable ether/alcohol bands of close wavenumbers.

The influence of temperature on the trilete spore wall has been studied by Yule et al. (2000). From the onset until late stages of thermal maturation the relative proportion of $\mathrm{C}=\mathrm{O}$ (about $1704 \mathrm{~cm}^{-1}$ ) decreases. The earliest stages of maturation accompanying the initial loss of oxygen are characterized by a relative increase in the aliphatic $\mathrm{CH}_{\mathrm{x}}$ band (about 2925-2854 $\mathrm{cm}^{-1}$ ) and $\mathrm{C}=\mathrm{C}$ bonds. The subsequent stages of maturation are characterized by a decrease in this aliphatic signal accompanying the development of aromatic structures, which are characterized by the band at ca. $1600 \mathrm{~cm}^{-1}$.

The trilete spore spectra of low maturity from Gotland show important similarities to that of spores of similar maturity analyzed by Yule et al (2000), including the relatively important aliphatic content, although the relative aliphatic content, characterized by the ratio $2925 \mathrm{~cm}^{-}$ $1 / 1600 \mathrm{~cm}^{-1}$ (Tbl. 1) shows some variation, ranging from 0.75 for $P$. rugosa up to 1.43 for $D$. murusdensa-murusattenuata). However, following the maturation trend of Yule et al. (2000), the relatively small shoulder at $1704 \mathrm{~cm}^{-1}$ in Gotland trilete spores would be consistent with highly coalified spores, which is not the case for these very low-rank spores. Yule et al. (2000) observed, moreover, the development of aromatic C-H bands below $1000 \mathrm{~cm}^{-1}$ only in highly coalified spores. We observe, however, important variations in this spectral region within similar very low-rank trilete spores (spectra 4.2, 4.3 and 4.4), which might be linked with variations in intensity of $\mathrm{O}$-bearing functional groups absorbing at slightly higher wavenumbers. Thus, we observe significant variation in several spectral features within a morphospecies from the same sample that has undergone the same geological history, as supported by (i) the absence of reworked palynomorphs, (ii) the consistent colour of the miospores and (iii) the similar aliphatic $\left(2925 \mathrm{~cm}^{-1}\right)$ vs. aromatic $\left(1600 \mathrm{~cm}^{-1}\right)$ content. These spectral features clearly diverge from the maturation trend of Yule et al (2000). While relative aliphatic content remains almost constant in the trilete spores (Fig. 4), the O-bearing functional group absorption and aromatic C-H absorption below $1000 \mathrm{~cm}^{-1}$ show significant variations. Interestingly, similar variations have been observed between artificially matured and fossil samples of similar colour analyzed by Yule et al (2000). These variations could be related to factors other than maturation, such as the ultrastructure of the spore exine, variation in the sporopollenin vs. taxonomy, or atmospheric oxidation of the samples.

Comparison of the spectra of the thick walled and a thin walled T. medinensis could result from the exine thickness and therefore of its ultrastructure. This case was straightforward because specimens can be differentiated under the dissecting microscope: the thin specimen is much lighter than the thick one. Note that this difference in colour does not result from different thermal maturity or from reworking. However, it is not so easy to differentiate 
morphologies among the other morphospecies analysed. Indeed, there is a continuous morphological variation from Retusotriletes sp. to Ambitisporites sp. The first does not have an equatorial thickening, unlike the second. Under the dissecting microscope it is relatively difficult to separate both. This case applies to the cryptospores $G$. divellomedia and $D$. murusdensa-murusattenuata. G. divellomedia and $L$. plicata are the end members of a morphon where $G$. divellomedia is thick walled and $L$. plicata thin walled. This is the same for D. murusdensa, thick, and D. murusattenuata, thin (Steemans et al., 1996). In the present study it was not possible to appreciate small variations in thickness under the dissecting microscope. Moreover, the ultrastructure of those different cryptospores shows considerable variation as demonstrated in different studies (Taylor, 1995, 1996, 1997, 2002, 2003; Wellman et al., 1998b). For example, G. divellomedia (Laevolancis divellomedia in Wellman et al., 1998b) can be subdivided into five distinct types as a result of detailed anatomical and ultrastructural analysis. Therefore, most probably the variations in wall thickness, "wall construction (homogenous, spongy, globular or some combination thereof), degree of fusion between adjacent spores and presence of tightly adherent envelope undetectable with the light microscope" (Taylor, 2002), may influence the spectra line shapes. The remarkable uniformity of the $P$. rugosa spectra argues in favour of this hypothesis. This morphospecies is indeed very characteristic and of low intra-specific variation. This could be confirmed by future combined analysis of the exine ultrastructure and the micro-FTIR analysis.

\subsection{Comparison of morphospecies spectra.}

Based on the general line-shape of the miospore spectra there are clearly three groups: (i) the two tetrad taxa T. medinensis and P. rugosa, (ii) the two monad taxa G. divellomedia and the dyads $D$. murusdensa-murusattenuata and, (iii) the trilete spore taxa

Retusotriletes/Ambitisporites spp.

Comparison of the band positions and their values is provided on the synthetic Tbl. 1.

(i) Both tetrad morphospecies show very characteristic spectra, with two moderate sharp and clearly differentiated absorption bands at 1500 and $1450 \mathrm{~cm}^{-1}$. The band at $1210 \mathrm{~cm}^{-1}$ is characteristic: moderate in T. medinensis, and strong and sharp in P. rugosa. Both display moderate aliphatic C- $\mathrm{H}_{\mathrm{x}}$ bands (at $2930-2860 \mathrm{~cm}^{-1}$ ). The band at $819 \mathrm{~cm}^{-1}$ is sharp for $P$. rugos $a$ and large for $T$. medinensis. The ratios $2925 \mathrm{~cm}^{-1} / 1604 \mathrm{~cm}^{-1}$ and $1604 \mathrm{~cm}^{-1} / 1500 \mathrm{~cm}^{-1}$ are respectively for $T$. medinensis 0.85 and 1.42 , and for $P$. rugosa 0.75 and 1.28 . The differences between both morphospecies most probably result from the presence of the ornamentation which covers the distal face of $P$. rugosa.

(ii) Spectra of the second group (monads and dyads) do not display strong bands at 1500 , 1210 and $820 \mathrm{~cm}^{-1}$. They have stronger aliphatic $\mathrm{C}-\mathrm{H}_{\mathrm{x}}$ bands (at $2930-2860 \mathrm{~cm}^{-1}$ ). The ratios $2925 \mathrm{~cm}^{-1} / 1600 \mathrm{~cm}^{-1}$ and $1600 \mathrm{~cm}^{-1} / 1500 \mathrm{~cm}^{-1}$ are respectively 1.34 and 2.40 for $G$.

divellomedia and 1.43 and 2.60 for $D$. murusdensa-murusattemuata. These values show the important similarities between the both morphospecies.

(iii) The Retusotriletes spp. do not display strong bands at 1500 and $1210 \mathrm{~cm}^{-1}$ but the band $820 \mathrm{~cm}^{-1}$ in some specimens is well differentiated. They display moderate aliphatic $\mathrm{C}-\mathrm{H}_{\mathrm{x}}$ bands (at $2930-2860 \mathrm{~cm}^{-1}$ ). The ratios $2925 \mathrm{~cm}^{-1} / 1604 \mathrm{~cm}^{-1}$ and $1604 \mathrm{~cm}^{-1} / 1500 \mathrm{~cm}^{-1}$ are respectively 0.99 and 1.64 , values similar to those of the first group (tetrads).

All these miospore spectra are clearly different from those of chitinozoan and leiosphere that do not present a $C=C$ aromatic band at $1500 \mathrm{~cm}^{-1}$ and a phenol band at $1210 \mathrm{~cm}^{-1}$. The $\mathrm{C}=\mathrm{C}$ 
aromatic carbon absorption is centred at higher wavenumber for the chitinozoan $\left(1613 \mathrm{~cm}^{-1}\right)$ and for the leiosphere $\left(1627 \mathrm{~cm}^{-1}\right)$, indicating different aromatic structures (Hudgins and Sandford, 1998a, b). In addition, the leiospheres and chitinozoans show several other specific characteristics : (i) leiosphere is unique to have a strong $\mathrm{C}=\mathrm{O}$ band at $1707 \mathrm{~cm}^{-1}$, (ii) leiosphere ratio $2960 \mathrm{~cm}^{-1} / 2925 \mathrm{~cm}^{-1}$ is the smallest (0.47), (iii) however, the ratio $2925 \mathrm{~cm}^{-}$ $1 / 1700 \mathrm{~cm}^{-1}$ is the greatest (1.96), (iv) but this ratio is the smallest for the chitinozoan $(0.43)$, (v) the leiosphere $2925 \mathrm{~cm}^{-1} / 1600 \mathrm{~cm}^{-1}$ ratio is the highest (1.78), characteristic of the high aliphaticity of such palynomorphs, (vi) whereas the same ratio applied to the chitinozoan is the lowest $(0.43)$. The aliphaticity ratio of the miospores is between these two extremes, with values ranging from 0.75 to 1.43 .

\subsection{The $1500 \mathrm{~cm}^{-1}$ band}

The aromatic $\mathrm{C}=\mathrm{C}$ band at $1500 \mathrm{~cm}^{-1}$ has a weak intensity, and is generally a simple shoulder, except in the spectra of the two tetrad morphospecies. The increase in intensity of this band is accompanied by less strong aliphatic $\mathrm{CH}_{\mathrm{x}}$ bands in the $2930-2850 \mathrm{~cm}^{-1}$ region and by important aromatic C-H bands in the $880-720 \mathrm{~cm}^{-1}$ region and likely results from increased $p$ alkyl substituted phenols. The $1500 \mathrm{~cm}^{-1}$ band is absent from the spectra of the leiosphere and the chitinozoan, and their second derivatives merely show an inflexion at this wavenumber.

Studies of recent spores have shown that the intensity of this aromatic $\mathrm{C}=\mathrm{C}$ band is correlated with the altitude and UV-B flux where the parent plants of the spores grow (Watson et al., 2007). Most probably all palynomorphs herein come from the same area, so, the variation in intensity of this band is more likely related to the composition of the tetrads vs. that of the dyads, monads and trilete spores. Recently, Gabarayeva et al. $(2009 \mathrm{a}, \mathrm{b})$ have shown the complexity of the physicochemical processes during miospore ontogeny from the late tetrad stage, through the post-tetrad period. Again, future joint analysis of the ultrastructure of the exine and micro-FTIR analysis are needed to solve those questions.

\section{Conclusions}

For the first time the chemical composition of cryptospores has been analysed. The microFTIR spectra demonstrate that their wall is composed of the same biopolymer as in trilete spores, i.e. sporopollenin. The band at about $1500 \mathrm{~cm}^{-1}(\mathrm{C}=\mathrm{C}$ aromatic) characteristic of sporopollenin (but also peat and lignite) was observed for all miospores, trilete spores and cryptospores. The band is absent from the chitinozoan and leiosphere spectra.

The line shapes in the ether/alcohol and aromatic $\mathrm{CH}$ bands from different specimens of the same morphospecies seem to be influenced by the thickness of the exine and the variation in the ultrastructure of the wall. In addition, laevigate and ornamented tetrads show slight differences, most probably due to the ornamentation.

The monad $G$. divellomedia and the dyad $D$. murusdensa-murusattenuata show very similar spectra. This is a predictable result, as the monads originate from the separation of the dyad spores. Late Silurian dyads are loosely attached and look more like a cluster of two monads than the early Silurian dyads, which are clearly tightly attached.

The two tetrads morphospecies have their four spores tightly pressed and show a significantly different spectrum from the other miospore morphospecies. They display two strong and 
sharp bands at about 1500 and $1210 \mathrm{~cm}^{-1}$. In addition $P$. rugosa has also a strong sharp band at about $820 \mathrm{~cm}^{-1}$.

These are preliminary results. More data are needed, especially in combining micro-FTIR spectroscopy with analysis of the ultrastructure of the palynomorph wall. This approach should allow testing hypotheses about the biological affinities of palynomorphs, their preservation and their palaeoecological history.

\section{Acknowledgments}

We thank M. Giraldo for the processing of the samples in the laboratory. J.R. Maxwell, editor-in-chief, is acknowledged for improving the manuscript. This manuscript greatly benefit from the comments and suggestions of Dr. N.S. Gupta (MIT-Carnegie Institution, USA) and an anonymous reviewer. P. Steemans is a Senior Research Associate of the NFSR and $\mathrm{K}$. Lepot receives a postdoctoral NFSR grant.

\section{References}

Arouri, K., Greenwood, P.F., Walter, M.R., 1999. A possible chlorophycean affinity of some Neoproterozoic acritarchs. Organic Geochemistry 30, 1323-1337.

Arouri, K., Greenwood, P.F.,Walter, M., 2000. Biological affinities of Neoproterozoic acritarchs from Australia: microscopic and chemical characterisation. Organic Geochemistry $31,75-89$.

Batten, D.J., 1996. Palynofacies and petroleum potential. In: Jansonius, J., McGregor, D.C. (Eds.), Palynology: Principles and Applications. American Association of Stratigraphic Palynologists Foundation, Salt Lake City, pp. 1065-1084.

Bernard, S., Benzerara, K., Beyssac, O., Menguy, N., Guyot, F., Brown, G. E., Goffe, B., 2007. Exceptional preservation of fossil plant spores in high-pressure metamorphic rocks. Earth and Planetary. Science. Letters., 262, 257-272.

Breuer, P., Al-Ghazi, A., Al-Ruwaili, M., Higgs, K.T., Steemans, P., Wellman, C.H., 2007. Early to Middle Devonian miospores from northern Saudi Arabia. Revue de Micropaléontologie, 50, 27-57.

Coates, J., 2000. Interpretation of infrared spectra, a practical approach. In: Meyers, R.A. (Ed.), Encyclopedia of Analytic Chemistry. John Wiley \& Sons Ltd, Chichester, pp. 10815-10837.

Cody, G. D., Botto, R. E., Ade, H., Wirick, S., 1996. The application of soft X-ray microscopy to the in-situ analysis of sporinite in coal. International Journal of Coal Geology, 32, 69-86.

De Leeuw, J.W., 2007. On the origin of sedimentary aliphatic macromolecules: A comment on recent publications by Gupta et al. Organic geochemistry 38, 1585-1587

De Leeuw, J.W., Versteegh, G.J.M., Van Bergen, P.F., 2006. Biomacromolecules of plants and algae and their fossil analogues. Plant Ecology 189, 209-233.

Dutta, S., 2006. Biomacromolecules of fossil algae, spores and zooclasts from selected time windows of Proterozoic to Mesozoic age as revealed by pyrolysis-gas chromatography-mass spectrometry - a biochemical study, 67. Schriften des Forschungszentrum Jülich, Reihe Umwelt/Environment, $139 \mathrm{pp}$.

Dutta, S., Brocke, R., Hartkopf-Froder, C., Littke, R., Wilkes, H., Mann, U., 2007. Highly aromatic character of biogeomacromolecules in Chitinozoa: A spectroscopic and pyrolytic study. Organic Geochemistry 38, 1625-1642. 
Edwards, D., Wellman, C.H., Axe, L., 1999. Tetrads in sporangia and spore masses from the Upper Silurian and Lower Devonian of the Welsh Borderland. Botanical Journal of the Linnean Society, 130, 111-156.

Gabarayeva, N., Grigorjeva, V., Rowley, J.R., Hemsley, A.R., 2009a. Sporoderm development in Trevesia burckii (Araliaceae) II. Post-tetrad period: Further evidence for the participation of self-assembly processes. Review of Palaeobotany and Palynology 156, 233-247.

Gabarayeva, N., Grigorjeva, V., Rowley, J.R., Hemsley, A.R., 2009b. Sporoderm development in Trevesia burckii (Araliaceae). I. Tetrad period: Further evidence for the participation of self-assembly processes. Review of Palaeobotany and Palynology $156,211-232$.

Gensel, P.G., 2008. The Earliest Land Plants. Annual Review of Ecology Evolution and Systematics 39, 459-477.

Grey, K., 1999. A modified palynological preparation technique for the extraction of large Neoproterozoic acanthomorph acritarchs and other acid insoluble microfossils. Record-Geological Survey of Western Australia 199, 1-23.

Gupta, N.S., Briggs, D.E.G., Collinson, M.E., Evershed, R.P., Michels, R., Pancost, R.D. 2007. Molecular preservation of plant and insect cuticles from the Oligocene Enspel Formation, Germany: Evidence against derivation of aliphatic polymer from sediment. Organic Geochemistry 38, 404-418.

Hagström, J., 1997. Land-derived palynomorphs from the Silurian of Gotland, Sweden. Geologiska Föreningens i Stockholm Förhandlingar 119, 301-316.

Hudgins, D.M., Sandford, S.A., 1998a. Infrared spectroscopy of matrix isolated polycyclic aromatic hydrocarbons. 2. PAHs containing. Journal of Physical Chemistry A 102, 329-343.

Hudgins, D.M., Sandford, S.A., 1998b. Infrared spectroscopy of matrix isolated polycyclic aromatic hydrocarbons. 2. PAHs containing five more rings. Journal of Physical Chemistry A 102, 344-352.

Iglesias, M.J., del Río, J.C., Laggoun-Défarge, F., Cuesta, M.J., Suárez-Ruiz, I., 2002. Control of the chemical structure of perhydrous coals; FTIR and Py-GC/MS investigation. Journal of Analytical and Applied Pyrolysis 62(1), 1-34.

Jacob, J., Paris, F., Monod, O., Miller, M.A., Tang, P., George, S.C., Bény, J.-M., 2007. New insights into the chemical composition of chitinozoans. Organic Geochemistry 38 , $1782-1788$.

Javaux, E.J., Marshall, C.P., 2006. A new approach in deciphering early protist paleobiology and evolution: Combined microscopy and microchemistry of single Proterozoic acritarchs. Review of Palaeobotany and Palynology 139, 1-15.

Kodner, R.B, Summons, R.E., Knoll A. H., 2009. Phylogenetic investigation of the aliphatic, non-hydrolyzable biopolymer algaenan, with a focus on green algae. Organic Geochemistry 40, 854-862.

Largeau, C., Derenne, S., Casadevall, E., Kadouri, A., Sellier, N., 1986. Pyrolysis of immature Torbanites and of the resistant biopolymer (PRB A) isolated from extant alga Botryococcus braunii. Mechanism of formation and structure of Torbanite. Organic Geochemistry 10, 1023-1032.

Laufeld, S., 1974. Silurian Chitinozoa from Gotland. Fossil and Strata 5, 1-130.

Le Hérissé, A., 1989. Acritarches et kystes d'algues prasinophycées du Silurien de Gotland, Suède. Paleontographia Italica 76, 57-302.

Marshall, C.P., Javaux, E.J., Knoll, A.H., Walter, M.R., 2005. Combined micro-Fourier transform infrared (FTIR) spectroscopy and micro-Raman spectroscopy of Proterozoic 
acritarchs: A new approach to Palaeobiology. Review of Palaeobotany and Palynology $138,208-224$.

Marshall, C.P., Carter, E.A., Leuko, S., Javaux, E.J., 2006. Vibrational spectroscopy of extant and fossil microbes: relevance for the astrobiological exploration of Mars. Vibrational Spectroscopy 41, 182-189.

Richardson, J.B., 1996a. Chapter 18A. Lower and Middle Palaeozoic records of terrestrial palynomorphs. In: Jansonius, J., McGregor, D.C. (Eds.), Palynology: principles and applications. American Association of Stratigraphic Palynologists Foundation, Salt Lake City, pp. 555-574.

Richardson, J.B., 1996b. Taxonomy and classification of some new Early Devonian cryptospores from England. In: Cleal, C.J. (Ed.), Studies on early land plant spores from Britain. Special Papers in Palaeontology, Great Britain, pp. 7-40.

Richardson, J.B., Ford, J.H., Parker, F., 1984. Miospores, correlation and age of some Scottish Lower Old Red Sandstone sediments from the Strathmore region (Fife and Angus). Journal of Micropalaeontolgy 3, 109-124.

Rouxhet, P.G., Robin, P.L., Nicaise, G.B., 1980. Characteristion of kerogens and their evolution by infrared spectroscopy. In: Durand, B. (Ed.), Kerogen. Editions Technip, Paris, pp. 163-190.

Steemans, P., 2000. Miospore evolution from the Ordovician to the Silurian. Review of Palaeobotany and Palynology, 113, 189-196.

Steemans, P., Wellman, C.H., 2004. Miospores and the emergence of land plants. In: Webby, B., Paris, F., Droser, M.L. , Percival, I.G. (Eds.), The Great Ordovician Biodiversification Event. Critical Moments and Perspectives in Earth History and Paleobiology. Columbia University Press, New York, pp. 361-366.

Steemans, P., Le Hérissé, A., Bozdogan, N., 1996. Ordovician and Silurian cryptospores and miospores from Southeastern Turkey. Review of Palaeobotany and Palynology 93, 3576.

Steemans, P., Javaux, E.J., Breuer, P., Le Herisse, A., Marshal, C.P., Ville de Goyet, F., 2009a. Description and microscale analysis of some enigmatic palynomorphs from the Middle Devonian (Givetian) of Libya. Palynology 33, 101-112.

Steemans, P., Le Herisse, A., Melvin, J., Miller, M.A., Paris, F., Verniers, J., Wellman, C.H., $2009 \mathrm{~b}$. Origin and radiation of the earliest vascular land plants. Science 324, 353.

Steemans, P., Petus, E., Breuer, P., Mauller-Mendlowicz, P., Gerrienne, P., in-press. Palaeozoic innovations in the micro- and megafossil plant record: from the earliest plant spores to the earliest seeds. In: Talent, J. (Ed.), Extinction intervals and biogeographic perturbations through time - Earth and Life. Springer.

Strother, P.K., Al-Hajri, S., Traverse, A., 1996. New evidence for land plants from the lower Middle Ordovician of Saudi Arabia. Geology 24, 55-59.

Taylor, W.A., 1995. Ultrastructure of Tetrahedraletes medinensis (Strother and Traverse) Wellman and Richardson, from the Upper Ordovician of Southern Ohio. Review of Palaeobotany and Palynology 85, 183-187.

Taylor, W.A., 1996. Ultrastructure of Lower Paleozoic dyads from Southern Ohio. Review of Palaeobotany and Palynology 92, 269-279.

Taylor, W.A., 1997. Ultrastructure of Lower Paleozoic dyads from southern Ohio II: Dyadospora murusattenuata, functional and evolutionry considerations. Review of Palaeobotany and Palynology 97, 1-8.

Taylor, W.A., 2002. Studies in cryptospore ultrastructure: variability in the tetrad genus Tetrahedraletes and type material of the dyad Dyadospora murusattenuata. Review of Palaeobotany and Palynology 119, 325-334. 
Taylor, W.A., 2003. Ultrastructure of selected Silurian trilete spores and the putative Ordovician trilete spore Virgatasporites. Review of Palaeobotany and Palynology, $126,211-223$.

Traverse, A., 2007. Paleopalynology. Topic in geobiology, 28. Springer, 813 pp.

Vandenbroucke, M., Largeau, C., 2007. Kerogen origin, evolution and structure. Organic Geochemistry, 38, 719-833.

Vavrdová, M., 1990a. Coenobial acritarchs and other palynomorphs from the Arenig/Llanvirn boundary, Prague basin. Věstník Českého geologického ústavu 65, 237-242.

Vavrdová, M., 1990b. Early Ordovician acritarchs from the locality Myto near Rokycany (late Arenig, Czechoslovakia). Casopis pro mineralogii a geologii 35, 239-250.

Watson, J.S., Sephton, M.A., Sephton, S.V., Self, S., Fraser, W.T., Lomax, B.H., Gilmour, I., Wellman, C.H. ,Beerling, D.J., 2007. Rapid determination of spore chemistry using thermochemolysis gas chromatography-mass spectrometry and micro-Fourier transform infrared spectroscopy. Photochemical \& Photobiological Sciences 6, 689. 694.

Wellman, C.H., Edwards, D., Axe, L., 1998a. Permanent dyads in sporangia and spore masses from the Lower Devonian of the Welsh Borderland. Botanical Journal of the Linnean Society 127, 117-147.

Wellman, C.H., Edwards, D., Axe, L., 1998b. Ultrastructure of laevigate hilate cryptospores in sporangia and spore masses from the Upper Silurian and Lower Devonian of the Welsh Borderland. Philosophical Transactions of the Royal Society of London 353, 1983-2004.

Yule, B.L., Roberts, S. and Marshall, J.E.A., 2000. The thermal evolution of sporopollenin. Organic Geochemistry 31, 859-870.

Figure (6), table (1) and plate (1) captions.

Fig. 1.

Location of sampling locality at Kättelviken, southern extremity of Gotland, Sweden.

Fig. 2.

Local chrono- and lithostratigraphy of the Ludlow (Late Silurian) from Gotland.

Fig. 3.

Average micro-FTIR spectra from three specimens of each morphospecies (except for the chitinozoan and leiosphere, a spectrum of a single specimen of each is represented).

Fig. 4.

4.1. Second derivative of Retusotriletes/Ambitisporites average spectra;

4.2-4.4. baselined spectra of three specimens of Retusotriletes/Ambitisporites;

4.5 ; second derivative of chitinozoan spectrum between $1800 \mathrm{~cm}^{-1}$ and $1200 \mathrm{~cm}^{-1}$.

4.6. baselined spectrum of one specimen of chitinozoan;

4.7. Second derivative of the leiosphere spectrum in between $1800 \mathrm{~cm}^{-1}$ and $1200 \mathrm{~cm}^{-1}$;

4.8. baselined spectrum of one specimen of leiosphere.

Fig. 5.

5.1. Second derivative of Gneudnaspora divellomedia average spectra;

5.2-5.4. baselined spectra of three specimens of Gneudnaspora divellomedia;

5.5. second derivative of Dyadospora murusdensa morphon average spectra; 
5.6-5.8. baselined spectra of three specimens of Dyadospora murusdensa morphon.

Fig. 6 .

6.1. Base lined spectra of one specimen of Tetrahedraletes medinensis (with a thin exine); 6.2-6.4. baselined spectra of three specimens of Tetrahedraletes medinensis (with a thick exine);

6.5. second derivative of Tetrahedraletes medinensis (with a thick exine) average spectra; 6.6-6.8. baselined spectra of three specimens of Pachytetras rugosa.

\section{Table 1.}

Band wavenumbers of each palynomorph (measured on average spectra) and their assignments using micro-FTIR spectroscopy. Comparisons between relative intensities of some bands. S, shoulders; grey boxes, characteristic bands or ratios to differentiate palynomorphs.

\section{Plate 1}

All specimens come from the same sample (sample 580 - slide 35469) containing the palynomorphs used for micro-FTIR analysis;

1-10. cryptospores (tetrads, 1-5; dyads, 6-8; monads, 9-10).

1-3. Tetrahedraletes medinensis Strother and Traverse emend. Wellman and Richardson 1993 of different exine thickness;

4-5. Pachytetras rugosa Hagström 1997;

6-8. Dyadospora murusdensa-murusattenuata morphon Steemans et al. 1995 of different exine thickness and showing different degrees of spore separation;

9-10. Gneudnaspora (Laevolancis) divellomedia Balme, 1988 var. divellomedia Breuer et al. 2007 of different exine thickness;

11 and 12. trilete spores;

11. Ambitisporites sp.;

12. Retusotriletes sp. 
Figure(s)

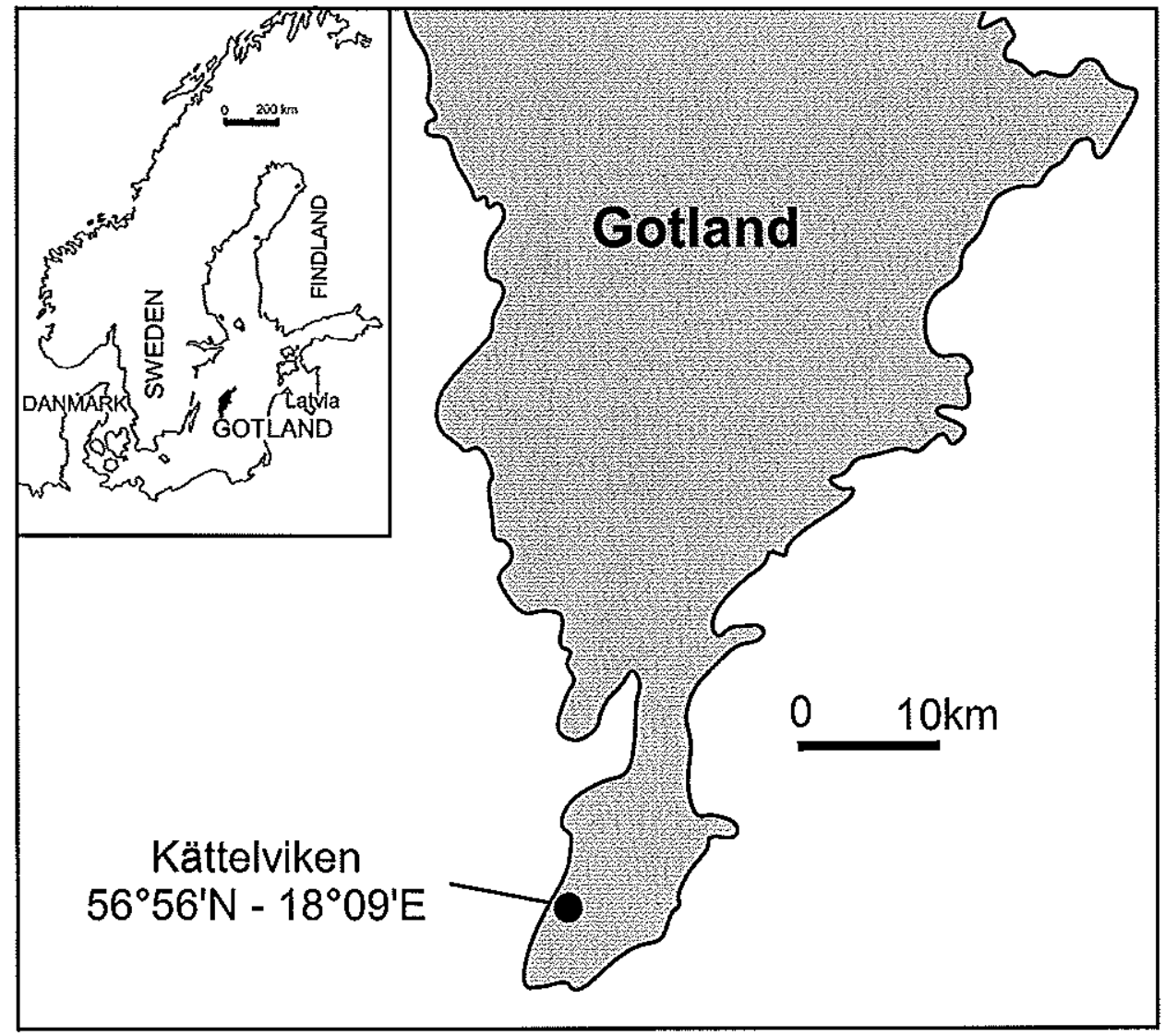


Figure(s)

\begin{tabular}{|c|c|c|}
\hline Series & Stages & $\mathrm{Fm}$. \\
\hline \multirow{8}{*}{ 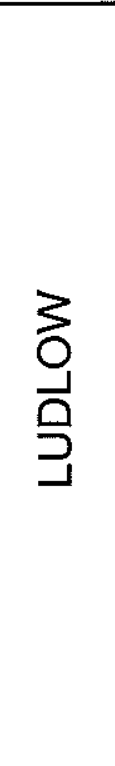 } & \multirow{3}{*}{ Whitcliffian } & Sundre \\
\hline & & Hamra \\
\hline & & Burgsvik \\
\hline & \multirow{2}{*}{$\begin{array}{l}\text { Leintwar- } \\
\text { dinian }\end{array}$} & Eke \\
\hline & & \multirow{3}{*}{ Hemse } \\
\hline & $\begin{array}{l}\text { Bringe- } \\
\text { woodian }\end{array}$ & \\
\hline & \multirow[t]{2}{*}{ Eltonian } & \\
\hline & & \\
\hline
\end{tabular}


Figure(s)
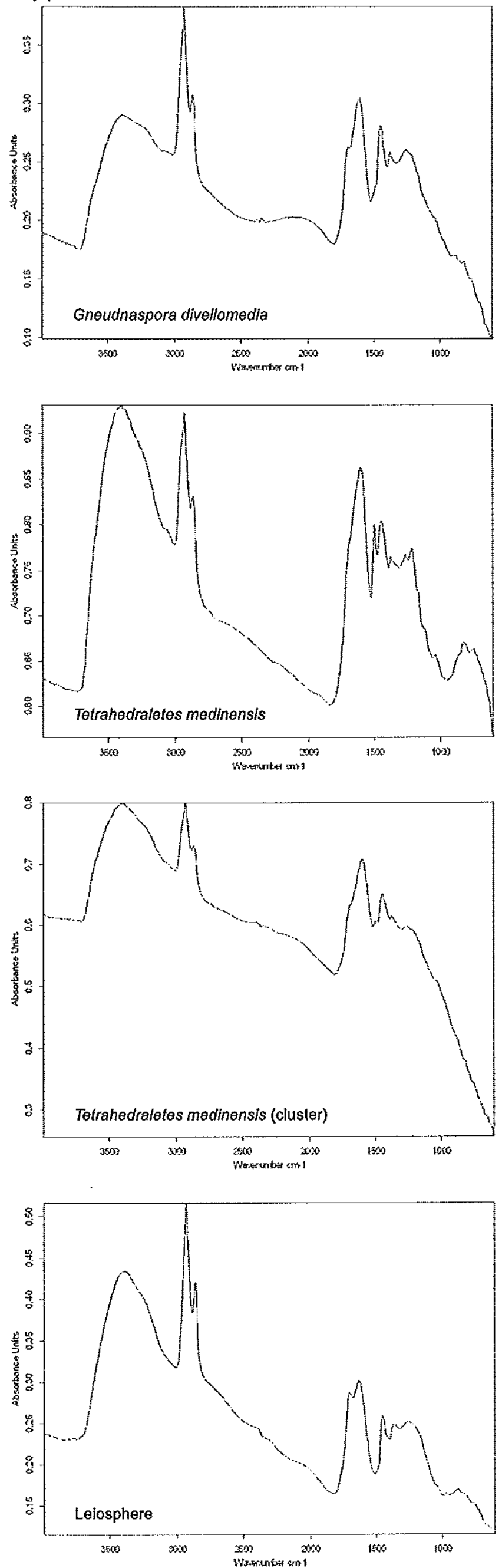
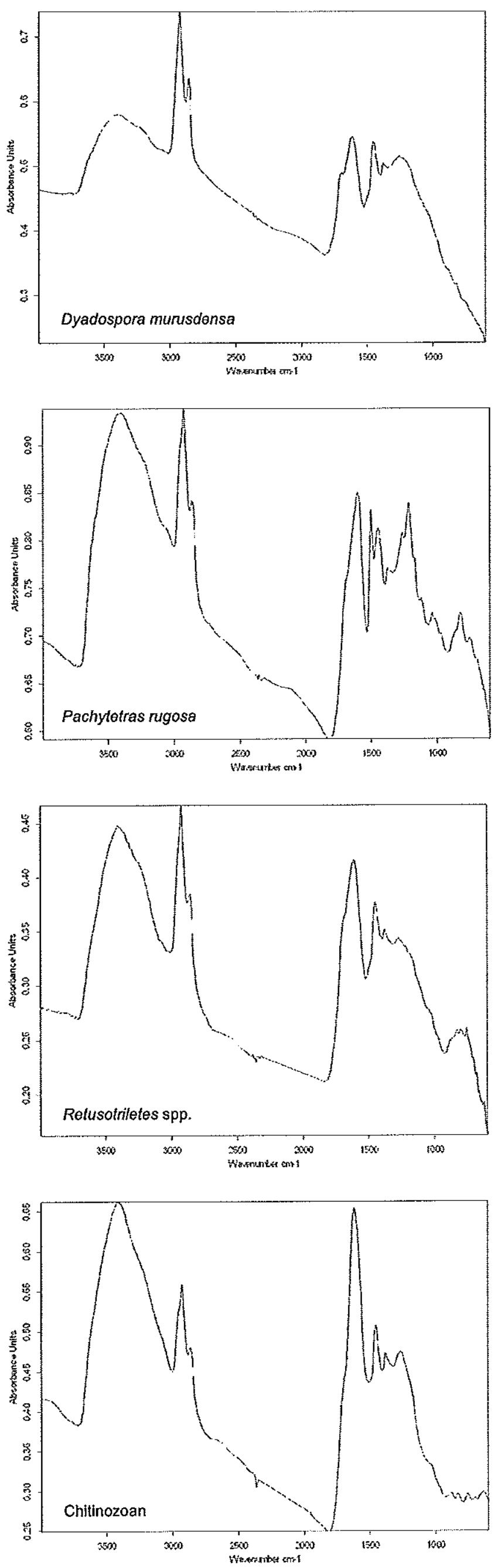
Figure(s)
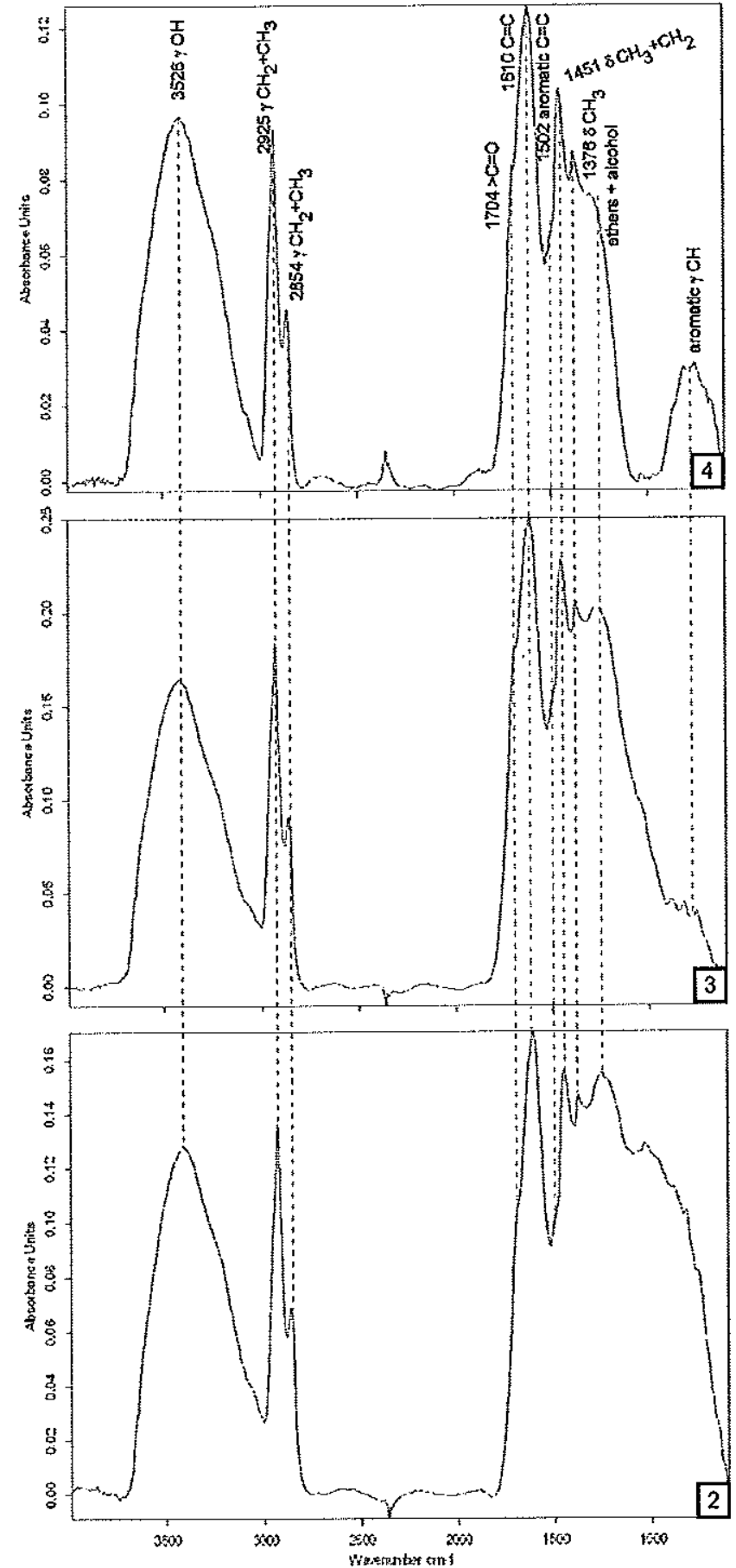

Retusotriletes spp.

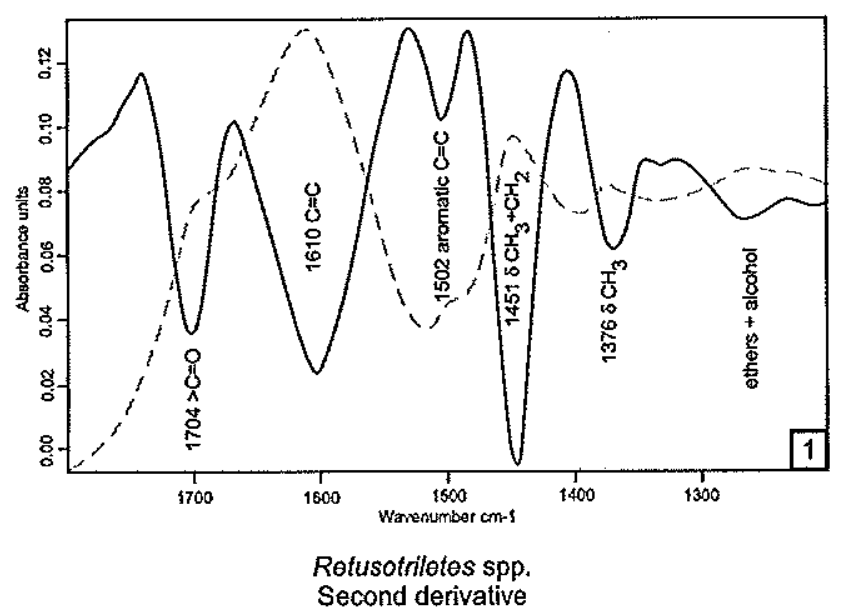

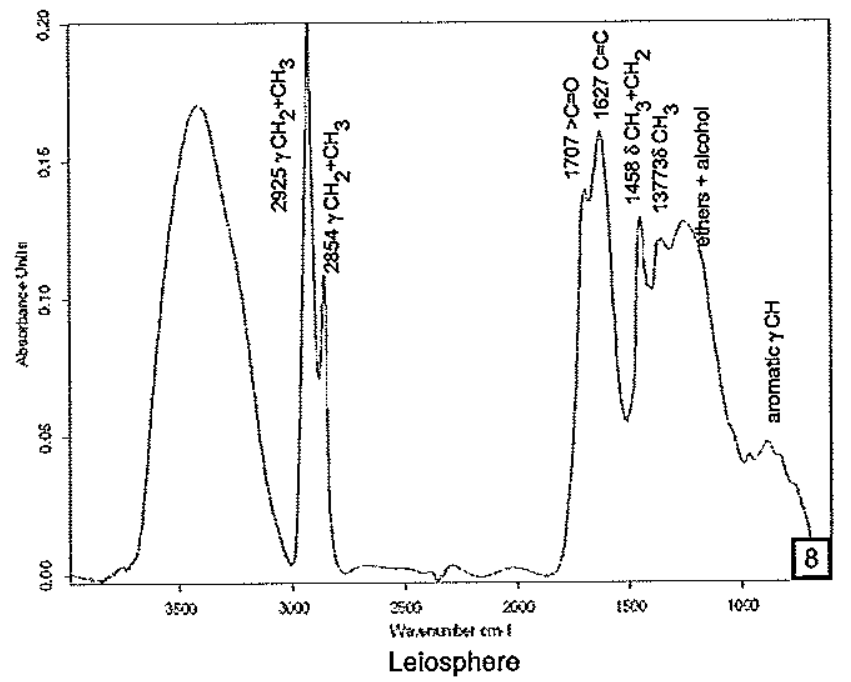
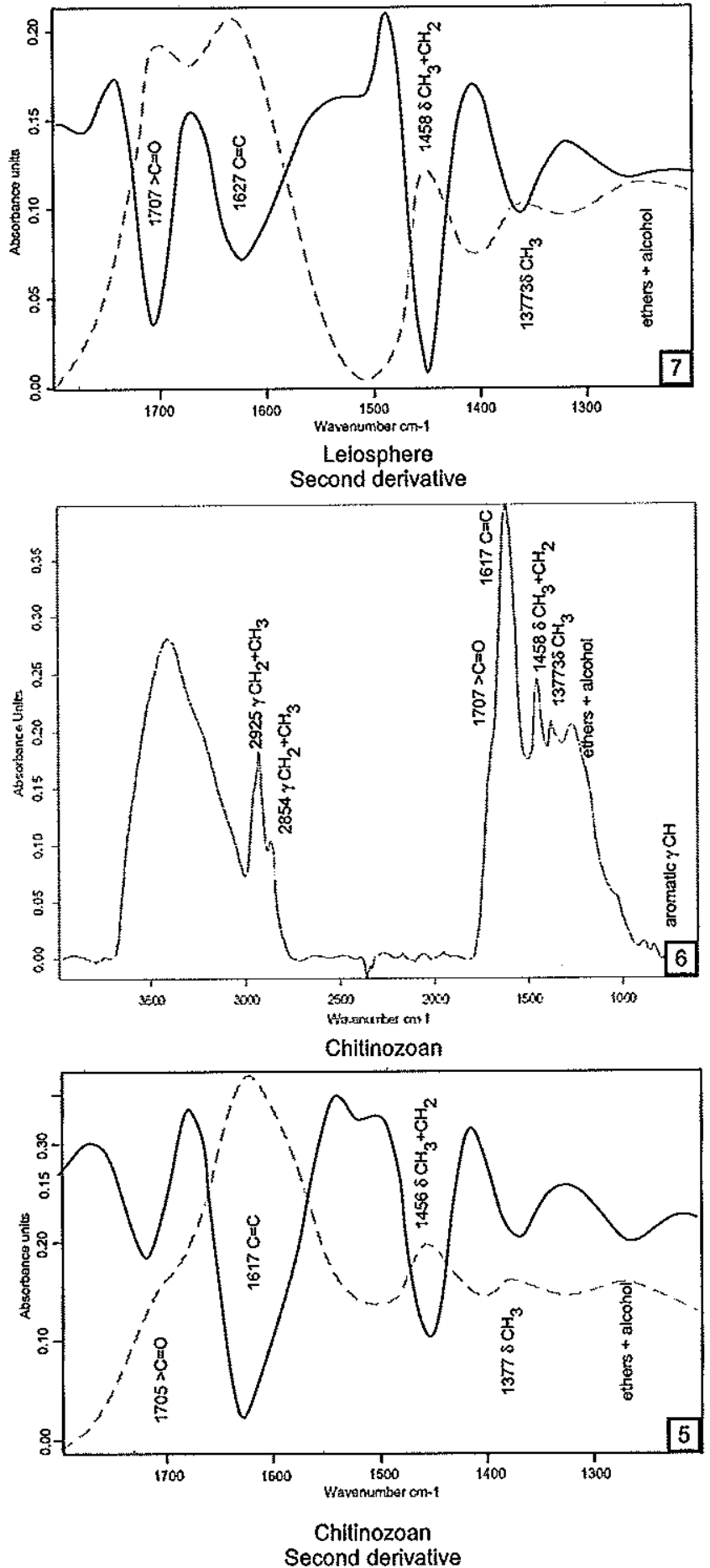
Figure(s)
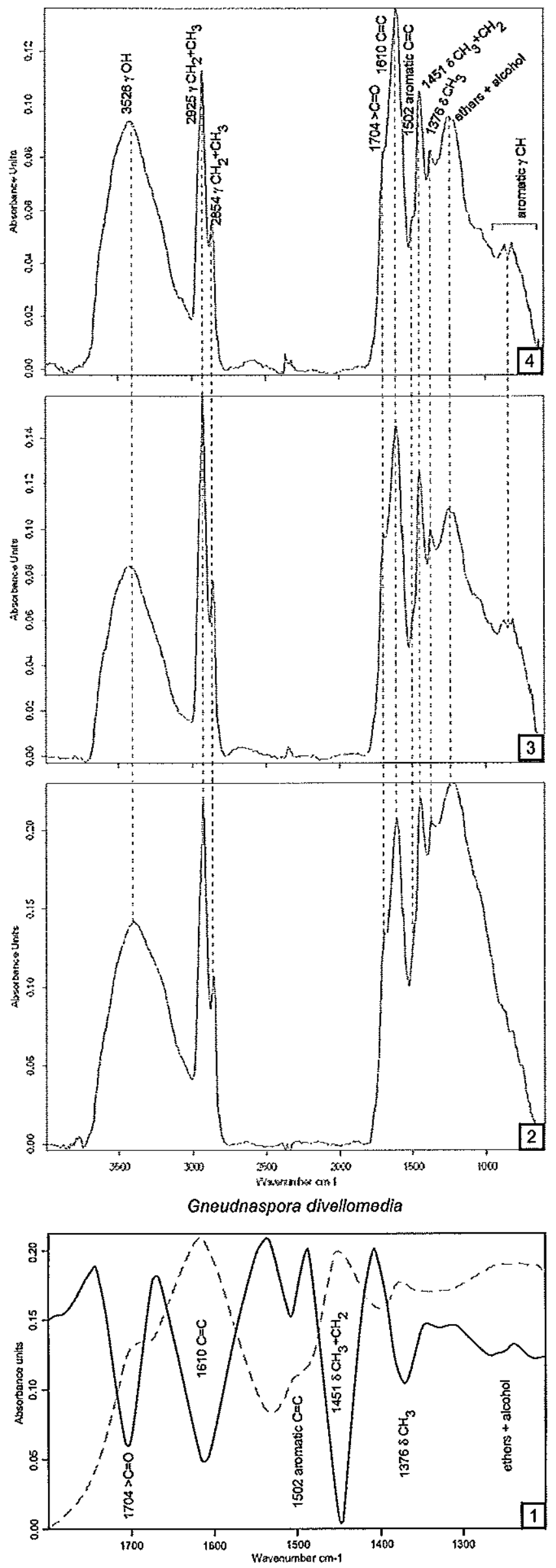

Gneudnaspora divellomedia

Second derivative
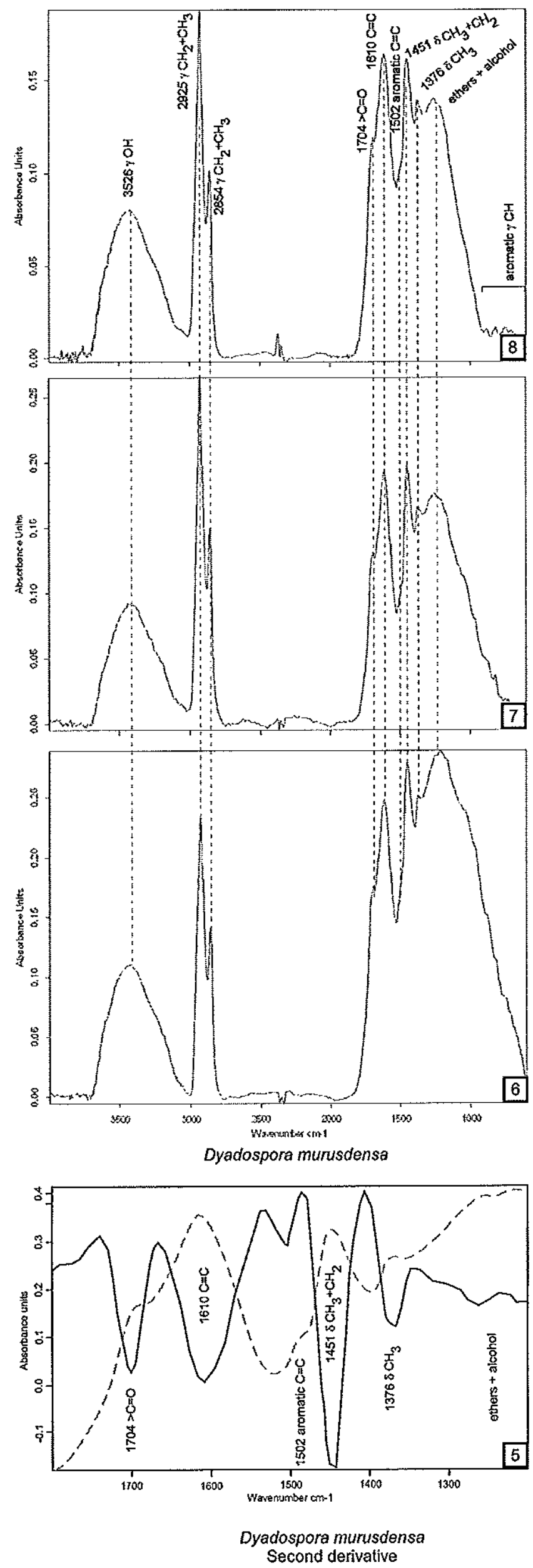
Figure(s)
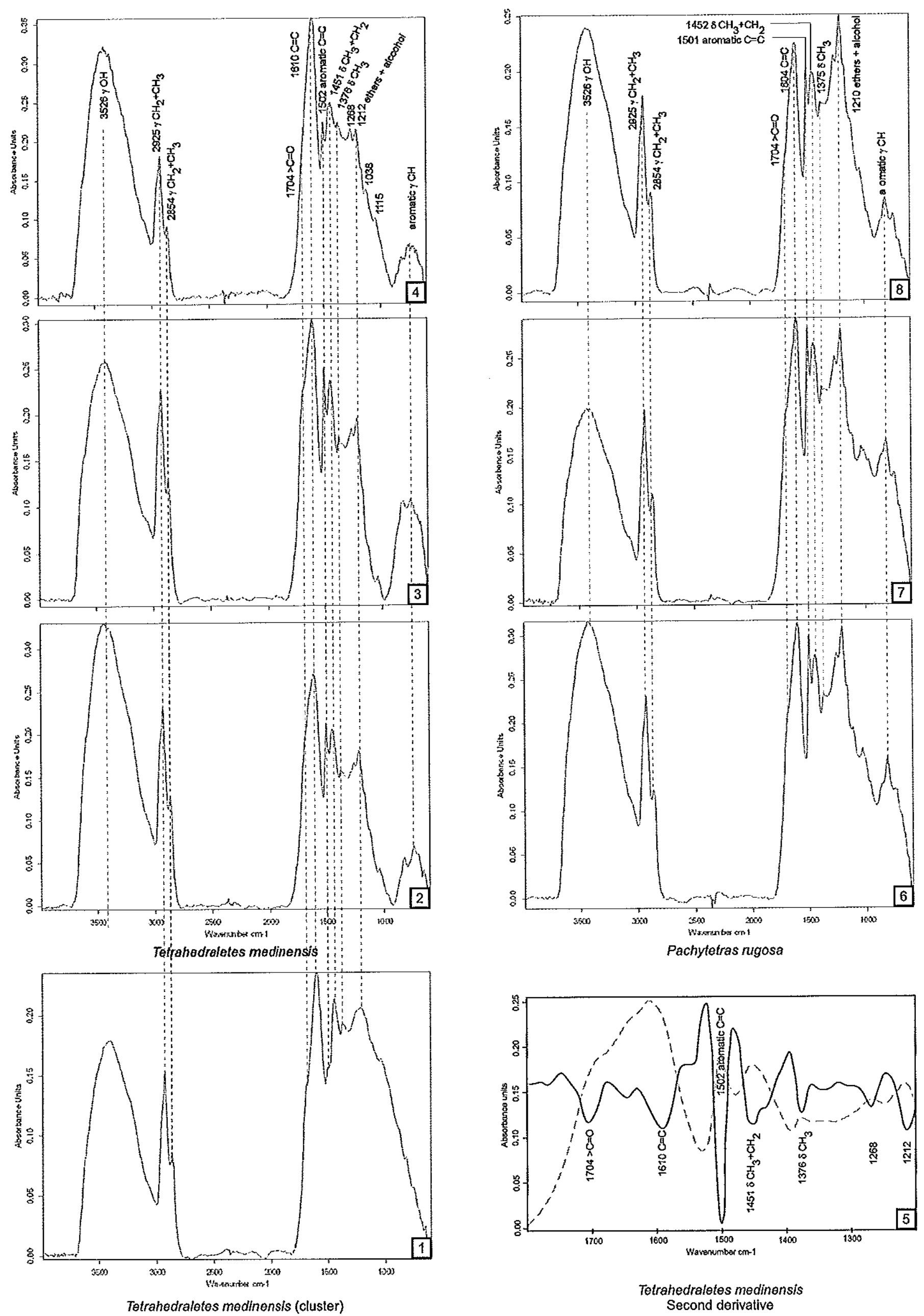
Figure(s)
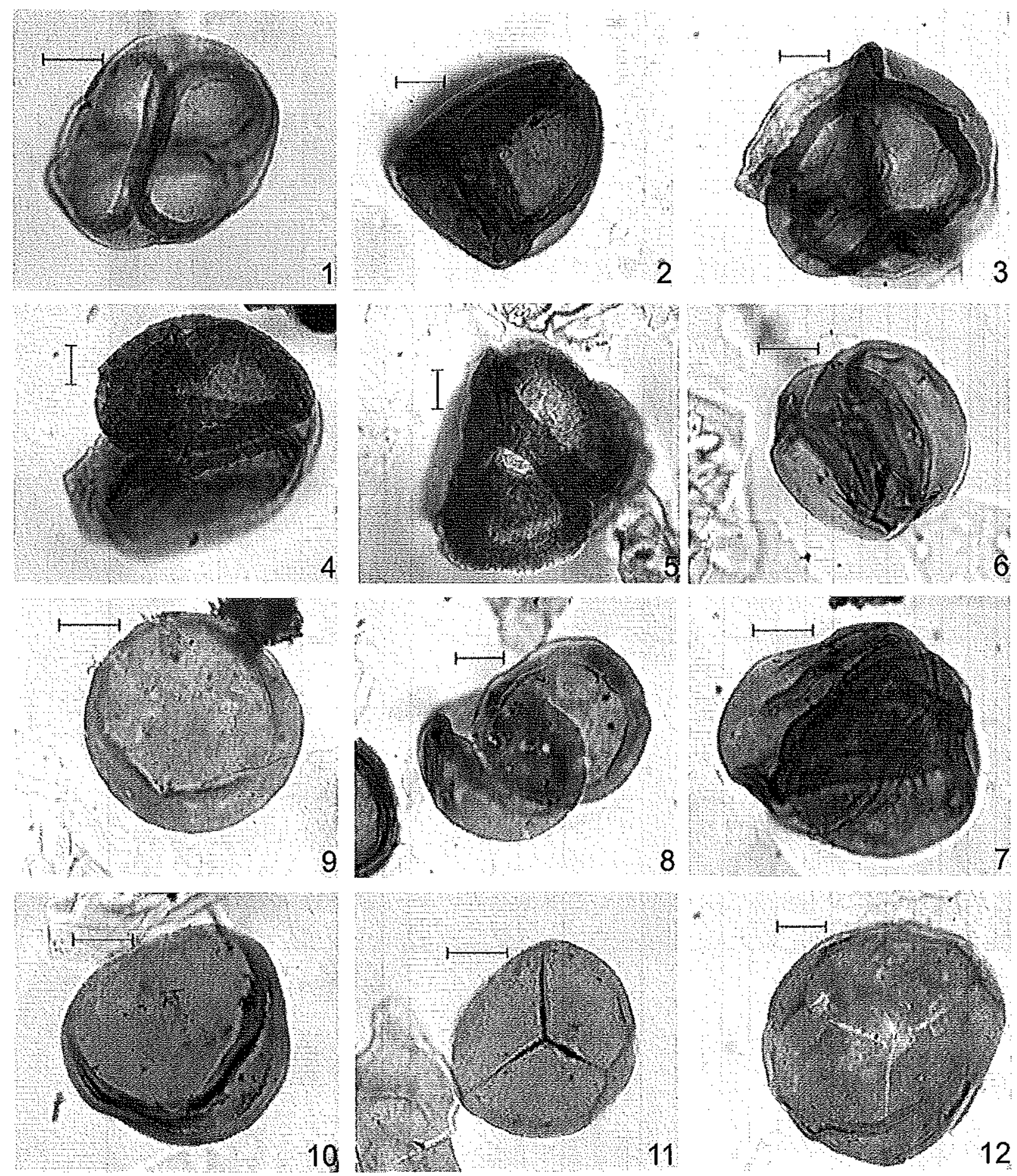


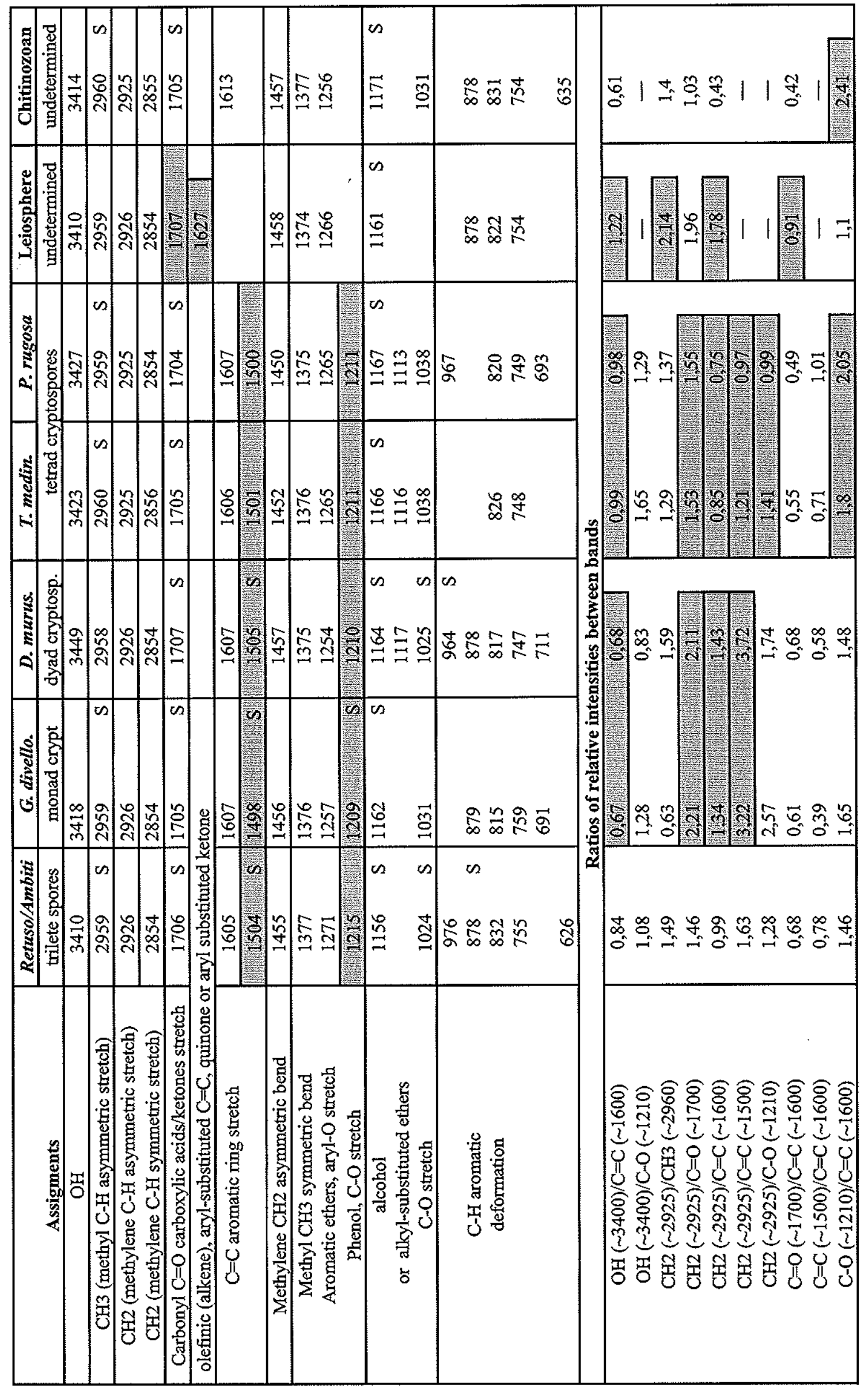

